\title{
Kontroversi Sekitar Produk Pangan Hasil Rekayasa Genetika
}

\author{
Nurhayati Abbas
}

\begin{abstract}
Genetically Modified Organism (GMO) is a relative new technology which applied to plants and cattle, to increase the quality of the food product.But many things organism have not been known by the experts, that could make unpredictable denger to the humanbeing ang the environment. Do the regultion as instrument for testing and to control the spread of the food product which contain genetically modified organism technology, should be applied.
\end{abstract}

\section{Pendahuluan}

Akhir-akhir ini menjadi bahan polemik di koran dan majalah baik yang merupakan terbitan nasional dan lokal maupun terbitan luar negeri seputar produk pangan yang dalam proses pengolahannya menggunakan bahan baku, bahan tambahan atau bahan pembantu yang merupakan hasil rekayasa genetika (GMO=Genetically Modified Organism).

Inti perbedaan pendapat di antara para ahli terutama menyangkut pertanyaan, apakah pangan seperti ini aman untuk dikonsumsi oleh makhluk hidup (terutama manusia), atau tidak. Berhubungan dengan dampak yang ditimbulkannya pada makhluk hidup tidak segeradapat terlihat atau terasakan, dan dapat bersifat irrevesible atau irretrievable (tidak dapat dipulihkan kembali), maka dapat dimengerti adanya kekhawatiran yang besar atas produk pangan seperti ini.

Kekhawatiran bukan hanya dilontarkan oleh para ahli yang berkecimpung di bidang kesehatan dan pengobatan (dokter dan ahli farmasi), tetapi terutama oleh para peneliti yang aktivitasnya sehari-hari berkecimpung dalam bidang modifikasi gen atau teknologi transgenik itu sendiri, serta ahli lingkungan. Mereka ini pada umumnya dapat dikelompokkan dalam golongan yang tidak menentang pemanfaatan teknologi rekayasa genetika dalam produk pangan secara massal, namun menghendaki adanya kehati-hatian yang tinggi. Maksudnya suatu produk pangan yang berbahan baku, bahan pembantu dan bahan tambahan yang merupakan hasil rekayasa genetika, hendaknya telah mengalami proses pengujian ayang lebih lama dan lebih teliti sebelum diedarkan dan dikonsumsi oleh prang banyak. Mereka memakai alasan bahwa sekali orang lalai dalam pemakaian produk seperti ini, maka dampak yang ditimbulkannya 
dapat sangat besar baik bagi manusia maupun bagi makhluk hidup lainnya.

Oleh karena disiplin limu yang penulls geluti sehari-hari bukan bidang rekayasa genetika dan juga bukan di bidang kesehatan, maka penulis tidak mempunyai kompetensi untuk membahas tentang aman tidaknya produk pangan sepert' ini, meskipun banyak juga disinggung pendapat ahli yang mengkhawatirkan pangan seperti ini. Hal yang ingin dibahas dalam tulisan singkat ini terutama menyangkut aspok hukumnya, yaitu tentang persyarakat yang harus dipenuhi agar produk pangan seperti ini dapat diedarkan di Indonesia, dan dikonsumsi oleh konsumen indonesia. Juga disinggung sedikit masalah yang berkait dengan etika atau moral serta agama.

Oleh karena itu permasalahan dari tulisan ini adalah, apakah produk pangan yang menggunakan bahan baku, bahan tambahan dan bahan bantu yang merupakan hasil rekayasa genetika dapat beredar di Indonesia, dan bagaimana seharusnya perlakuan terhadap produk pangan seperti ini?

\section{Pengertian Umum}

Rekayasa genetika merupakan teknologi yang relabif baru, baik di luar negeri maupun di Indonesia. Usianya baru sekitar 30 tahun. ${ }^{1}$ Namun demikian karena kemajuan teknologi dan pengaruh perdagangan bebas, maka apa yang merupakan ciptaan Allah yang kemudian diutak-atik oleh para ahli di suatu negeri, dalam waktu relatif singkat sudah diproduksi secara massal dan beredar di sleuruh dunia, terutama di negeri-negeri berkembang. Produk darl pangan yang memakai teknologi rekayasa genetlka memanfaatkan kelemahan yang pada umumnya terdapat di negeri-negeri berkembang (khususnya Indonesia), yaltu penegakan dan penerapan hukumnya yang sangat lemah.

Pasal 1 butir 12 dari UU Pangan (UU No. 17 tahun 1996) memberl pengertian secara sederhana tentang rekayasa genetika sebagal berikut:

"Rekayasa genetika adalah suatu proses yang melibatkan pemindahan gen (pembawa sifat)'dari suatu jenis hayati ke jenis hayati lain yanig berbeda atau sama untuk mendapatkan jenis baru yang mampu menghasilkan produk pangan yang lebih unggul."

Sedang dalam Pasal 1 ayat (5) dari Surat Keputusan Bersama (SKB) Menteri Kehutznan dan Perkebunan, Menteri Kesehatan, dan Menteri Negara Pangan dan Hortikultura (SKB No. 998.1/Kpts/OT.2109/99; No. 1145 A Menkes/SKB IXJ1999; No. 790.a/KPTS - IXJ 1999) tentang Keamanan. Hayati dan Keamanan Pangan Produk Pertanian Hasil Rekayasa Genetika (Disingkát SKN tentang Keamanan Hayati dan Keamanan Pangan) ditentukan sebagai berikut:

"Teknologi rekayasa gentika adalah segala upaya untuk mengadakan perubahan secara sengaja pada genon makhluk hidup dengan menambah, mengurangi dan/atau mengubah susunan asli genon dengan menggunakan teknik DNA rekombinan.'

' Consumers Associationb of Penang. Yang Pentu Diketahui Tentang Makanan Hasil Rekayasa Genetika (Jakarta: YLKI, 2002), hlm. 35 
Secara sederhana dapat dijeloaskan bahwa rekayasa genetika' (kadang-kadang disebut pula sebagai bioteknologi, teknologi gen, teknologi transgenik atau rekombinan) merupakan tindakan ilmuan yang mengbah DNA (asam deoksiribonukleat) atau susunan genetika makhluk hidup. Mereka memotong gen tertentu dari DNA suatu organisme dan menyisipkannya ke dalam DAN makhluk hidup lain yang tidak sekerabat atau sama sekali berbeda, seperti anusia, babi, kambing, jamur bakteri, dan lain-lain. ${ }^{2}$ Hasilnva adalah teripta makhluk hidup yang merupakan kreasi manusia di laboratorium, yang sebelumnya tidak pernah ada. Misalnya buah tomat yang mengandung gen ikan flounder yang hidup Laut Utara (North Sea), yang menyebabkan buah ini tahan terhadap cuaca dingin dan tidak cepat rusak dalam cuaca dingin/beku. Atau mungkin pula semacam tikusyang sangat besar karena telah disisipi dengan gen manusia yang berhuibungan dengan pertumbuhan. Pemindahan gen ikan ke dalam buah-buahan ini dilakukan dengan memanfaatkan bakteri atau virus yang akan menyerang dan menyisip ke dalam DAN sel induk. Jadi dua (atau lebih) organisme yang memiliki DNA yang berberda dikombinasikan oleh manusia dengan sengaja dalam waktu yang relatif singkat.

Menurut Sutanto ${ }^{3}$ sampai dengan tahun 1997 sudäh ada 124 "organisme baru" yang dipatentkan untuk dibudidayakan dan dipasarkan secara global. Bioteknologi ini membuat manusia mampu melewati batas biologi, baik pada hewan, tanaman, maupun mikroorganisme dengan memasukkan sifat yang diinginkan oleh penciptanya.

Akan tetapi, karena pengetahuan manusia tentang DNA dari berbagai' jenis organisme itu masih sangat terbatas, maka masih banyak hal yang tidak dapat dikendalikan oleh manusia, sehingga sering muncul hasil yang tidak terduga, seperti gen manusia ketika disisipkan ke dalam DNA babi, hasilnya bukan babi yang sangat besar (mencontoh tikus tadi), tetapi babi yang sakit-sakitan, pincang dan bermata juling.

Utak-atik gen seperti itu dilakukan oleh para ahli . terhadap tumbuh-tumbuhan dan binatang ternak, dengan tujuan meningkatkan. dan menyempurnakan kualits tumbuhan atau ternak itu, agar kebutuhan manuia akan pangan (pertanian dan peternakan) dapat lebih terpenuhi: Misalnya buah yang lebih cepat menjadi ranum, lebih besar, lebih terang warnanya, lebih menarik bentuknya, dan lebih enak rasanya. Atau mungkin pula binatang ternak yang lebih cepat besar sehinigga tidak terlalu membutuhkannya banyak pakan ternak sudah dapat dipasarkan, serta berdaging lebih banyak. Namun, karena'seperti apa yang telah dikemukakan sebelumnya bahwa pengetahuan manusia tentang gen dari berbagai organisme ini masih sangat terbatas, maka tidak selamanya tujuan yang ingin dicapai (menyempurnakan dan meningkatkan mutu), benar-benar berhasil. Atau kalau toch berhasil dicapai seperti pa yang diinginkan oleh penciptanya, belum tentu benar-benar lebih baik bagi manusia. contohnya buah-buahan hasil rekayasa genetika yang tahan

${ }^{2}$ bid., him.10

${ }^{3}$ Harian Kompas, 28 Juni 2000 
berminggu-minggu di toko dan kelihatan masih segar, kemungkinan nilai gizinya sudah sangat berkurang.

Harus diakui jauh sebelumnya manusia telah dan selalu berusaha untuk meningkatkan mutu ternak dan tanamannya dengan cara menyeleksi secara alamiah atau mengkombinasikan dua orgaasme yang masih sekerabat atau berhubungan. Misalnya padi varietas tertentu dikombinasikan dengan padi verietas lainnya sehingga lahirlah verietas padi yang baru. Kombinasi antara dua atau lebih varietas padi yang dilakukan secara tradisional Ini akan menghasilkan keturunan yang varietas ciri atau sifatnya tidak tidak terlalu jauh berbeda dari orang tuanyalinduknya. Sedangkan dengan teknik rekayasa genetika modern, varietas padi tertentu itu dikomboinasikan dengan gen dari tanaman yang bukan padi, atau mungkin dengan hewan, virus, jamur, atau manusia, hasilnya adalah lahir jenis padi yang varietas sifat atau cirinya sangat berbeda dengan induknya, bahkan mungkin di luar dugaan penciptanya sendiri. Oleh karena itu hampir semua ahli yang concern dengan masalah lingkungan hidup dan kesehatan manusia, menuntut diterapkannya prinsip pencegahan dini (precautionally principle) sebagaimana yang di syaratkan oleh Protokol Cartagena: Artinya pengembangan dan penyebarluasan organisme hasil rekayasa genetika serta produk turunannya selayaknya dilakukan setelah melalui pengujian yang teliti dan memenuhi standard ilmiah (uji pra klinik dan uji klinik). Juga dalam Protokol ini ditentukan bahwa produk transgenik yang belum jelas dampaknya dari segi kesehatan dan lingkungan, tidak boleh dilepas ke lingkungan. Untuk itu terlebih dahulu harus dilakukan risk management dan risk assessment. ${ }^{4}$ Ini berarti bahwa produsen harus membuat penilaian dan perhitungan-perhitungan tentang kemungkinan timbulnya dampak yang membahayakan, serta bagaimana mengendalikan dampak itu. Apalagi jika benar apa yang dikemukakan oleh Surapati ${ }^{5}$ bahwa pada tahun 2007 nanti akan terdapat 157 juta Ha tanaman transgenik di seluruh dunia. Ini berarti bahwa prinsip pencegahan dini dan prinsip kehati-hatian tidak dapat ditawar-tawar karena menyangkut keselamatan dunia dan seluruh isinya.

Dapat dimengerti bahwa untuk produk pangan dituntut persyaratan yang lebih berat lagi, oleh karena suatu produk pangzan yang memanfaatkan teknologi rekayasa genetika sedikit atau banyak menimbulkan resiko bagi konsumennya. Oleh karena itu sebelum produk seperti ini dilemparkan ke pasar ada beberaapa pertanyaan mendasar yang berkaitan dengan etika dan moral yang harus dijawab dahulu.

Pihak yang ekstrim meragukan manfaat tenologi rekayasa genetika, masih mempertanyakan apakah manusia mempunyai hak untuk mengutak-atik ciptaan Allah dengan menciptakan organisme baru yang lain atau belum pernah ada sebelumnya? Bahkan ada yang berpendapat bahwa sulit untuk memastikan apakah produk pangan seperti ini memang berguna untuk manusia. penuli tidak akan melibatkan diri dalam menjawab pertanyaan ini. Kiranya pihak yang menguasai dalil-dalil agama dan etika lebih kompeten

\footnotetext{
${ }^{4}$ Harian Kompas, 13 September 2000

${ }^{5}$ Harian Fajar, 12 Oktober 2002
} 
untuk menjawabnya,

Penulis lebih memusatkan diri pada pertanyaan lainnya yaitu apakah produk pangan yang memanfatkan teknologi rekayasa genetika sudah diuji keamanannya sesuai dengan proses pengujlan yang rasional, dalam jangka waktu yang panjang serta sesuai dengan standard kehati-hatian yang disyaratkan oleh Protokol Cartagena, UUPangan, SKB tentang Keamanan Hayati dan Keamanan Pangan, serta PP tentang Label dan Iklan Pangan? Dengan jawaban ya, artinya prinsip kehati-hatian telahg diterapkan sebelum produk ini diproduksi secara massal dan dipasarkan ke seluruh dunia.

\section{Hak-hak Konsumen dan Etika}

Pasal 4 Undang-undang Perlindungan Konsumen (UUPK) mencantumkan ada sembilan hak dari konsumen. Dari yang sembilan itu empat diantaranya sudah sangat sering diucapkan dalam pertemuanpertemuan ilmiah serta dalam literatur, yaitu:

- Hak atas keamanan produk (The right to safety product);

- Hak untuk memilih (The right to choose);

- Hak untuk mendapat informasi yang benar

(The right to be informed);

- Hak untk didengar pendapatnya/keluhannya (The right to be heard).

Keempat hak utama ini saling berkaitan satu sama lain, dan bersangkut paut dengan moral atau etika.
Fuady, ${ }^{6}$ berpendapat bahwa Hukum Perlindungan Konsumen (HPK) memang berada diantara Etika dan Hukum Ekonomi. Demikian pula dengan Patton, ${ }^{7}$ yang melihat bahwa prinsip-prinsip pertanggungjawaban harus berdasarkan moral dan masyarakat. Oleh karena itu maka tidaklah mengherankan jika keputusan hakim di negara-negara yang HPK sudah sangat berkembang, sering mempertimbangkan hal-hal yang berkaitan dengan etika, seperti keharusan untuk berhatihati pada kedua belah pihak, penerapan asas kelayakan dan kepatuhan serta itikad baik, serta prinsip perlindungan kepada konsumen yang posisi tawarnya (bargaining position) sangat lemah.

Agak berbeda sedikiit adalah pendapat dari Wahjono $0^{8}$ yang melihat HPK sebagi bidang hukum yaning bercorak cross sectoral, yaitu berada pada berbagai ranting hukum yaitu Hukum Fagang, Hukum Administrasi ${ }_{i}$ Hukum Perdata, Hukum Pidana, Hukum Internasional dan sebagainya. Oleh karena itu menurut pendapat Penulis tidak mengherankan jika uraian tentang produk pangan yang memanfaatkan teknologi rekayasa genetika selalu dikaitkan pula dengan UU di bidang HAKI, yaitu UU Paten, UU Merek dan sebagainya.

Kembali kepada empat hak konsumen tadi, maka hak atas keamanan seharusnya menajdi fokus utama dari produsen pangan. Negara-negara Eropa sangat serius dalam -menerapkan hak ini. Buktinya mereka menolak

${ }^{6}$ MunirFuady, "Product Liability dalam Hukum Bisnis Indonesia," Pro Justisia Tahun XII, April 1994. Bandung, hlm. 182

${ }^{7}$ George Whitecross Patton, A Text Book of Jurisprudence (Surabaya: Pustaka Tinta Mas, 1952), hlm. 218

${ }^{8}$ Munir Fuady, op.cit., him. 195-197. 
keju dan susu yang berasal dari AS karena dicurigai berasal dari sapi yang disuntik dengan hormon hasil rekayasa genetika. ${ }^{9}$

Bagaimana dengan Indonesia? Tampaknya sikap hati-hati seperti ini belum ada. Contohnya kedelai impor dari As yang hampir pasti merupakan hasil rekayasa genetika, tidak disikapi secara serius oleh Pemerintah. Data menunjukkan bahwa $80 \%$ dari produksi kedelai AS berasal dari benih hasil rekayasa genetika, dan ini tidak pernah dipersoalkan oleh aparat yang terkait. ${ }^{10}$ Keadaan ini telah berlangsung sejak tahun 80 -an, sehingga hampir pasti pula semua orang Indonesia yang pernah mengkonsumsi tahu, tempe, kecap dan sebgainya tanpa sadar telah mengkonsumsi kedelaj seperti ini, karena sebagian besar kebutuhan kedelai Indonesia diimpor dari AS. Keadaan ini menunjukkan bahwa hak konsumen atas keamanan dan informasi yang benar, sudah diabaikan baik oleh produsennya di AS, maupun oleh produsen produk turunannya (kecap, kripik tempe, air tahu, susu kedelai dan sebgainya), serta oleh Pemerintah Indonesia sendiri. Padahal Pasal 13 UU Pangan (UU No. 7 tahun 1996) telah mengharuskan produsen yang memproduksi pangan yang memanfaatkan bahan baku, bahan tambahan dan bahan bantu yang memakai teknologi rekayasa genetika, untuk memeriksakan keamanan pangan seperti ini. Juga ditentukan bahwa Pemerintah menetapkan syarat dan prinsip penelitian, pengembangan dan pemanfaatan metode rekayasa genetika dalam proses produksi pangan, serta menetapkan persyaratan pengujian pangan yang dihasilkan dari proses rekayasa genetika.

Dalam SKB tentang Keamanan Hayati dan Keamanan Pangan telah diatur bahwa setiap orang/badan yang akan memanfaatkan produk pertanian hasil rekayasa genetika (PPHR) wajib mengajukan permohonan pengkajian keamanan hayati dan keamanan pangan' kepada Menteri Kesehatan (Dirjen Pengawasan Obat dan Makanan) untuk hasil olahan hewan, ikan dan tanaman transgenik serta jasad renik transgenik yang digunakan untuk bahan dan proses pembuatan pangan (Pasal 37 ayat (1) butir d).

Berdasarkan permohonan tersebut maka dilakukan evaluași oleh Tim Teknis Keamanan Hayati dan Keamanan Pangan (TTKHKP) yang akan memberi laporan serta rekomendasi kepada Menteri, yang akan menjadikannya sebagai dasar pertimbangan apakah permohonan itu akan disetujui atau tidak. Selanjutnya orang/badan yang telah mendapat persetujuan dari Menteri harus membuat laporan secara berkala (tiap 12 bulan) kepada Menteri (Pasal 44).

Juga berdasarkan SKB ini ditentukan bahwa pemanfaatan produk pangan hasil $r$ rekayasa genetika (PPHRG) harus memenuhi persyaratan keamanan hayati dan keamanan pangan serta mempertimbangkan kaidah agama, etika, sosial budaya dan estetika.

Demikian pula dalam PP No. 69 tahun 1999 (PP tentang Label dan Iklan Pangan) ditentukan bahwa keterangan tentang bahan yang digunakan dalam proses produksi pangan harus tercantum dalam label (Pasal 19).

\footnotetext{
${ }^{9}$ Harian Kompas, 13 Juni 2000.

${ }^{10} \mathrm{Harian}$ Kompas, 25 Januari 2003
} 
Keamanan dalam Pasal 35 lebih tegas lagi diatur, yaitu bahwa pada label pangan yang memanfaatkan bahan baku, bahan pelengkap dan bahan bantu hasil teknologi rekayasa genetika, harus mencantumkan tulisan Pangan Hasil Rekayasa Genetia. Keharusan ini selayaknya juga berlaku untuk pangan yang tidak langsung dikonsumsi oleh manusia, seperti benih dan pakan ternak yang nantinya akan dikonsumsi oleh manusia. Bahkan Pasal 58 b dari UUP mencantumkan sanksi pidana terhadap pelaku usaha (PU) yang melanggar ketentuan tentang pengujian ini, yaitu penjara tiga tahun dan/atau denda Rp.360.000.000,-

Apakah ketentuan-ketentuan ini telah diterapkan? Tampaknya belum demikian, terbukti dari banyaknya protes dari LSM yang menaruh perhatian mengenai haal ini seperti YLKI, Konphalindo, PAN (Pesticide Action Network) serta protes dari perorangan. Mereka meminta kepada pemerintah agar segera menerapkan sistem keamanan pangan hasil rekayasa genetika, antara lain dengan menerapkan peraturan tentang pelabelan serta pengawasan yang insentif atas produk seperti ini.

YLKI ${ }^{11}$ telah mengumukan temuan yaitu kurang lebih. 81 produk pangan dan hasil turunannya ternyata positifmengandung bahan baku, bahan tambahan, atau bahan bantu yang merupakan hasil rekayasa genetika. Semua produk itu dipasarkan tanpa mencantuman keterangan pada label atau kemasan seperti yang disyaratkan oleh UU Pángan dan PP tentang label dan Iklan Pangan.

Dapat dibayangkan betapa banyaknya pelanggaran yang telah dilakukan oleh para PU di bidang pangan. Khusus untuk kedelai saja, mulai dari produsennya di AS, sampai dengan produsen produksi turunannya (tempe, kripik tempe, susu kedelai, kecap dan sebagainya), tidak ada yang memberi keterangan kepada konsumen tentang adanya kandungan hasil rekayasa genetika ini.

Dari pemberitaan di koran dan majalah terlihat bahwa semua protes yang diajukan tidak mendapat respon yang memadai dari produsen/perwakilannya di Indonesia. Apalagi karena adanya kecenderungan dari pemerintah Indonesia untuk dengan mudah meloloskan produk rekayasa genetika tanpa melalui uji lapangan yang memadai. Ini terbukti dari adanya SK menteri Pertanian No. 107/Kpts! KB.430/2/2001 yang mengizinkan penanaman kapas transgenik yang disebarkan di tujuh kabupaten di Sulawesi Selatan,l meskipun ada protes dari Menteri Lingkungan Hidup .12

Masalah hukum lainnya yang juga bersangkutan dengan etika adalah apa yang pernah dilontarkan oleh peneliti LIPI dan BATAN ${ }^{13)}$ dan Ketua YLKII4 yaitu penerapan standard ganda oleh pemerintah negara asal. Artinya ada kalanya suatu produk tidak diperkenankan urituk dikonsumsi olehmanusia dinegara äsalnya, dilemparkan sebagai bahan pangan manusia di negara lain (khususnya negara berkembang). Ataukah untuk pasar Eropa mereka melakukan pengujian yang teliti

\footnotetext{
1 Harian Kompas, 8 Februari 2002

${ }^{12}$ Harian Kompas, 18 Desember 2002

${ }^{13}$ Harian Kompas, 21 Juni 2000

${ }^{14}$ Harian Kompas, 13 Juni 2000
} 
sebelum dipasarkan, sedangkan untuk negaranegara berkembang karena longgarnya pengawasan, maka mereka menggunakan standard keamanan yang lebih rendah, artinya pengujiannya lebih sederhana. Keadaan ini sangat mencemaskan, karena tingkat ilmu dan teknologi sekarang belum dapat mengetahui apa yang akan terjadi 10-20 tahun setelah manusia mengkonsumsi pangan seperti itu. Jadi efek jangka panjangnya belum dapat terlihat sekarang. Contohnya yang sering dikemukakan adalah penemuan DDT beberapa dekade yang lalu, yang dianggap sebagai "penyelamat umat manusia" dari bahaya kelaparan, kegagalan panen, serta penyakit malaria. Ternyata kemudian racun yang dihasilkannya telah hampir memusnahkan species elang botak yang ada di AS. Ini terbukti dari ditemukannya reside DDT pada cangkar telur burung elang ini, yang gagal menetas.

Sikap menduadari pemerintah AS juga dicurigai dengan diundang-undangkannya UU Antiterorisme Biologi (The Bio Terrorism Act) di AS. Berdasarkan UU ini pemerintah menerapkan pengawasan yang sangat ketat terhadap produk pertanian dan perikanan yang diimport dari negara lain, akan tetapi di lain pihak sangat longgar dalam meloloskan produk pertanian AS yang akan dieksport ke negara lain (khususnya ke negara berkembang). Tindaan ini dicurigai sebagai upaya AAS untuk melindungi produk pertaniannya dengan kebijakan yang bersifat non-tarif (non-tarifbarrier). Sesuatu yang bertentangan dengan kesepakatan WTO, yang pelopor utamanya adalah
AS sendiri.

Produsen produk pangan hasil rekayasa genetika kelihatannya sangat memanfaatkan peluang yang ada, baik di negara asalnya (adanya standard ganda) maupun di negara tempat pemasaran produknya (lemahnya penegakan hukum).

Belum lagi jika produsen berusaha menghindari tanggungjawabnya dengan dalih state of the art, yaitu tingkat ilmu pengetahuan dan teknologi pada saat produski dilakukan belum memungkinkan bagi produsen untuk mengetahui kemungkinan timbulnya dampak yang merugikan bagi konsumen.

Bahaya bagi makhluk dan lingkungan akan makin besar kemungkinannya jika benar pada tahun 2007 nanti akan terdapat 157 juta Ha lahan tanaman transgenik. ${ }^{15}$ Dapat dibayangkan betapa besarnya dampak yang dapat ditịnbulkan jika penerapan ketentuan tentang pengujian, pengawasan dan pelabelan pangan seperti ini tidak dilaksanakan.

Menurut Consumers Association of Panang ${ }^{16}$ metode pengujian obat yang dilakukan oleh industri farmasi yang biasanya memakan waktu dan biaya yang besar, dilakukan terhadap binatang percobaan kemudian terhadap manusia. namun demikian $13 \%$ dari obat baru yang dilepas ke pasar tetap gagal dideteksi efeknya yang merugikan. Dari angka itu 3\% harus ditarik karena efek merugikan yang tidak terduga. $10 \%$ sisanya menimbulkan efek samping yang sangat serius, sehingga harus dibatasi pemakaiannya.

Pengujian untuk organisme transgenik

\section{${ }^{15}$ Fajar, 12 Oktober 2002}

${ }^{18}$ Nurhayati Abbas, Tanggung Jawab Produk Terhadap Konsumen dan Implementasinya pada Produk Pangan, (Pascasarjana Universitas Hasanudin, 20.02), hlm. 35 
dilakukan dalam waktu yang singkat dan pada sedikit binatang percobaan. Monsanto (suatu perusahaan yang besar yang banyak memproduksi organisme transgenik), melakukan pengujian pada hormon bovin rekombinan yang disuntikkan pada sapi agar mampu memproduksi lebih banyak susu, hanya selama 90 hari dan pada 30 ekor tikus. Padahal pengujian seperti itu membutuhkan waktu minimal dua tahun dan menggunakan sekurang-kurangnya beberapa ratus ekor tikus (pengujian standar untuk kanker). Namun demikian, pengujian yang singkat dan pada sedikit tikus itu telah menunjukkan banyak dampak, baik pada tikus maupun sapi. Akan tetapi, anehnya karena FDA (Food and Drug Administrastion) tetap memberikan persetujuan terhadap hormon itu. Pengujian oleh Monsanto yang diserahkan kepada FDA ini, juga tidak pernah dibuka untuk umum agar dapat dilakukan tinjauan ilmiah yang independen, karena dilarang oleh FDA. Demikian pula pengujian untuk kedelai Roundup Ready (RPS) hanya dilakukan terhadap ikan selama 10 minggu, serta pengujian yang lebih singkat pada sejumlah kecil ayam, tikkus dan sapi. ${ }^{17}$

Dari bukti.ini tidak mengherankan jika para peneliti dari BATAN, LIPI dan YLKI curiga akan adanya standard ganda yang diterapkan oleh pemerintah negara produsen, pangan transgenik.

Apakah konsumen pernah didengar pendapatnya tentang hal-hal yang merugikan keamanannya ini? Dari pemberitạan di media masa kelihatannya suara-suara dari LSM yang mewakili konsumen tidak mendapat respons yang memadai dan produsen atau perwakilannya di Indonesia. Apalagi karena adanya kecenderungan dari pemerintah untuk meloloskan dengan mudah produk rekayasa genetika tanpa pengujian yang memadai. Semua uraian di atas menunjukkan bagaimana produsen pangan dan nonpangan yang diamnfaatkan teknologi transgenik telah mengabaikan hak-hak konsumen berupa hak atas keamanan, hak atas informasi yang benar dan jujur, hak untuk memiliki serta hak untuk didengar pendapatnya.

Keberatan lainnya dari pihak yang medalami teknologi rekayasa genetika adalah disisipkannyà suicide seed (benih bunuh diri atau sering pula disebut sebagai teknologi terminator).pada benih pangan yang diproduksinya: Ini berarti bahwa dari hasil panen nanti petani tidak dapat menyisihkan sebagian untuk dijadikan bibit, karena bibit ini tidak akan tumbuh. Akibatnya setiap musim menanam, petani harus membeli bibit baru lagi dari produsen. Hal ini mengakibatkan ketergantungan terusmenerus dari petani terhadap produsen bibit.

Masalah hukum berikutnya yang berkaitan 'dengan etika dan agama, adalah kemungkinan penggunaan/penyisipan unsur DNA dari babi atau binatang lainnya seperti anjing dalam DNA tanaman pangan atau ternak. Ini tentu saja tidak dapat diterima oleh konsumen yang beragama islam. Oleh karena itu produsen pangan seperti ini seyogyanya mencantumkan keterangan yang jelas, agar hak konsumen akan informasi yang benar dan jujur serta hak untuk memilih benar-benar ditegakkan.

${ }^{17}$ Consumers Association of Penang, op.cit., hlm. 36-37 
Hak lainnya yang juga sangat penting adalah hak konsumenuntuk didengar pendapatnya atau keluhannya. Oleh karena berbagai hambatan sosial, budaya, pendidikan dan sebagainya, maka pada umumnya konsumen Indonesia khususnya di bidang pangan sangat pasif (kalau tidak dapat dikatakan sangat apatis). ${ }^{18}$ Dalam hal ini YLKI sudah sangat tepat dalam menyuarakan kepentingan konsumen seperti yang telah dikemukakan di atas.

Tak kalah pentingnya tentu adalah peranan Departemen Agama dan organisasi yang bergerak di bidang keagamaan untuk membicarakan dan mencari dali yang dapat menjadi landasan bagi pemerintah untuk mengambil tindakan yang tepat terhadap produk pangan import yang menggunakan unsur babi dan binatang haram lainnya dalam teknologi rekayasa genetika di bidang pangan. Alangkah bijaksananya jika organisasi yang berlandasan agama meraih kembali simpati dari masyarakat dengan melibatkan diri pada hal-hal yang bersifat ilmiah dan keagamaan.

Kembali ke soal pengujian produk pangan yang menggunakan teknologi rekayasa genetika, Pemerintah hendaknya segera mengeluarkan peraturan pelaksanaan di bidang ini, agar aparat yang kompenten untuk melakukan pengujian mempunyai patokan yang jelas.

Demikian pula UU Paten harus cukup jelas enentukan apakah semua temuan di bidang rekayasa genetika dapat dipatenkan. Apakah misalnya DNA manusia yang disisipkan pada DNA sapi agar susu yang dihasilkannya mirip dengan ASI termasuk yang dapat dipatenkan? Oleh karena itu UU
Paten Indonesia masih perlu dibenahi agar lebih jelas temuan (invention) mana yang dapat dipatenkan, dan tidak semata-mata berpatokan pada unsur kebaruan (novelty). Temuan di bidang rékayasa genetika meskipun mengandung unsur kebaruan tetapi jika bertentangan dengan etika atau moral bangsa apalagi dengan agama, hendaknya tidak diberi peluang untuk dipatenkan di Indonesia. Banga Indonesia sudah terlalu banyak kecolongan di bidang sosial-budaya, jangan lagi nilai-nilai moral yang kita anut didikte oleh banga lain.

\section{Gugatan Perwakilan Kelompok / Class Action}

Melihat kenyataan bahwa sebagian besar konsumen pangan tidak menyadari kemungkinan adanya bahayayang tersembunyidi balik produk pangan (terutama impor) yang berbahan baku, bahan pelengkap dan bahan pembantu yang merupakan hasil teknologi rekayasa genetika, maka menurut Penulis sudah saatnya YLKI serta LSM lainnya mengajukan gugatan perwakilan kelompok terhadap PU (pelaku usaha) di bidang pangan yang menyalahi ketentuan tentang label dan iklan pangan. Kalau dahulu yang menjadi hambatan adalah tidak adanya ketentuan yang mengatur mekanisme gugatan perwakilan kelompok, maka dengan keluarnya Peraturan Mahkamah Agung No. 1 Tahun 2002 maka upaya itu telah dapat ditempuh oleh pihak yang merasa dirugikan. Banyak keuntungan yang diperoleh dengan dijukannya para PU di bidang pangan yang menyalahi ketentuan hukum yang berlaku, dan yang paling utama

\footnotetext{
${ }^{18}$ Nurhayati Abbas, op.cit., h/m. 238.
} 
adalah hak konsumen akan keamanan produk yang dikonsumsinya dapat ditegakkan.

\section{Simpulan}

Produk pangan yang memakai bahan baku, bahan pelengkap dan bahan bantu yang merupakan hasil teknologi rekayasa genetika dapat beredar di Indonesia asal dipenuhi ketentuan tentang pelabelan, pengujian dan pengawasan yang terdapat dalam UUPK, UU Pangan, SKB tentang Kemanan Hayati dan Kemanan Pangan dan PP tentang Label dan Iklan Pangan. Namun dalam kenyataan pelaksanaan dari ketentuan hukum ini belum dilaksanakan, sehingga pengujian untuk tujuan itu belum pernah dilakukan oleh aparat yang kompeten di Indonesia

Mengingat dampak yang ditimbulkan oleh pangan. yang memanfaatkan teknologi rekayasa genetika dapat tak terduga besarnya, maka hendaknya Pemerintah segera melaksanakan peraturan pelaksanaan yang berkaitan dengan pengujian, pengawasan dan lain-lain pangan seperti itu. Dengan demikian hak-hak konsumen berupa hak atas keamanan, hak untuk' memperoleh informasi yang benar dan jujur, hak untuk memilih serta hak untuk didengar pendapatnya, juga sudah lebih ditunjang penegakannya.

Juga hendaknya Pemerintah juga tidak terlalu mudah membuka pasar dalam negeri dari sebuah produk pangan negara lain, mengingat seringnya Pemerintah negara produsen pangan menerapkan standard ganda, yaitu mempersulit impor pangan dari negara lain khususnya negara berkembang, dengan alasan kekhawatiran akan bioterrorism. Akan tetapi di lain pihak sangat memudahkan ekspor produk pangan $k \theta$ negara berkembang walaupun belum melalui pengujian yang sesuai standard.o

\section{Daftar Pustaka}

Abbas, Nurhayati, Tanggung Jawab Produk terhadap Konsumen dan Implementasinya pada Produk Pangan, Pascasarjana Unhas, Makassar, 2002.

Fuadi, Munir, "Product Liability dalam Hukum Bisnis Indonesia," Pro Justitia Tahun XII, April 1994, Bandung.

Consumers Association of Penang, Yang Perlu Diketahui tantang Makanan Hasil Rekayasa Genetika, Jakarta: YLKI, 2002.

Syawali, .Husin dan neni Sri Imaniyati (Penyunting), Hukum Perlindungan Konsumen, Bandung: Mandar Maju, 2000.

Surapati, Untung, "Biopolitik, Bioetika dan Tanaman Transgenik, " Fajar ; 12 Oktober 2002

Patton, George Whitecross, A Text Book of Jurisprudence, Surabaya: Pustaka Tinta Mas, 1952.

Harian Kompas 13 Juni 2000.

Harian Kompas, 13 September 2000.

Harian Kompas 28 Juni 2000.

Harian Kompas, 8 Februari 2002.

Harian Kómpas, 18 Desember 2002.

\section{EOEDE}

